\title{
Weed management of bulb flowers in Poland and other European Union countries
}

\section{Ochrona przed chwastami roślin ozdobnych uprawianych z cebul i bulw w Polsce i innych krajach Unii Europejskiej}

\author{
Ewa Matyjaszczyk ${ }^{1}$, Adam Dobrzański $^{2}$
}

\section{Summary}

The problem of weeds in ornamental bulb plantings (tulip, daffodil, iris, gladiolus, and lily) and weed management is reviewed in this paper. Ecological niche for weeds, floristic structure of weed communities and weed population dynamics in bulb plantings depends on different agrobiological factors. Ornamental bulbs are susceptible to weed infestation, particularly during the early stages of growth, but it is better to keep the crop weed free throughout lifecycle, because weeds cause yield reduction, may alter quality and size of bulbs and flowers quality. These plants do not shade out weeds that emerge in the rows and are fairly shallow rooted and care must be taken not to prune these roots with inter-row mechanical cultivation. Therefore, in integrated weed control strategies herbicides ought to be included. Ornamental bulbs belong to minor crops. In spite of it in most of countries herbicides are registered for use in ornamental bulbs to ensure necessary protection. Among others: chlorpropham, pendimethalin, linuron, metamitron, clopyralid, glyphosat and some graminicides are authorized and recommended. The possibilities of weed control on Poland in comparison to other countries is discussed.

Key words: ornamental bulbs, ornamental tubers, weed, herbicide, minor crops, plant protection legislation, plant protection products, use recommendation

\section{Streszczenie}

W pracy omówiono problem chwastów i możliwości ich zwalczania w roślinach ozdobnych uprawianych z cebul i bulw (tulipan, lilia, narcyz, kosaciec, mieczyk). Nisza ekologiczna chwastów, skład florystyczny i dynamika populacji chwastów w uprawach tych roślin zależy od różnych czynników agrobiologicznych. Są one szczególnie wrażliwe na zachwaszczenie w początkowym okresie wegetacji, ale lepiej utrzymywać plantację bez chwastów aż do zbioru. Chwasty obniżają plon, zmniejszają wielkość cebul i pogarszają jakość kwiatów. Rośliny te słabo pokrywają liśćmi powierzchnię międzyrzędzi, dlatego słabo konkurują z chwastami. Mają też dość słaby system korzeniowy, który łatwo uszkodzić podczas mechanicznego odchwaszczania. Dlatego, w integrowanej ochronie przed chwastami zaleca się stosowanie herbicydów. Cebulowe rośliny ozdobne zaliczane są do upraw małoobszarowych. Pomimo tego w większości krajów do ich ochrony zarejestrowane i zalecane są różne środki chwastobójcze. Między innymi: chlorprofam, pendimetalina, linuron, metamitron, chlopyralid, glifosat i różne graminicydy. Porównano możliwości zwalczania chwastów w Polsce z innymi krajami.

Słowa kluczowe: rośliny ozdobne cebulowe i bulwiaste, chwasty, herbicydy, uprawy małoobszarowe, prawodawstwo dotyczące ochrony roślin, środki ochrony roślin, zalecenia stosowania

\footnotetext{
1 Instytut Ochrony Roślin - Państwowy Instytut Badawczy Władysława Węgorka 20, 60-318 Poznań

e.matyjaszczyk@iorpib.poznan.pl

${ }^{2}$ Instytut Ogrodnictwa

Konstytucji 3 Maja 1/3, 96-100 Skierniewice

Wyższa Szkoła Humanistyczno-Ekonomiczna

Mazowiecka 1B, 96-100 Skierniewice

adam.dobrzaski1@neostrada.pl
} 


\section{Wstęp / Introduction}

Rośliny ozdobne uprawiane z cebul (tulipan, narcyz, lilia, cebulica syberyjska, czosnek ozdobny, hiacynt, kosaciec) i bulw (mieczyk, krokus) są uznawane za wrażliwe na zachwaszczenie, bo słabo konkurują $\mathrm{z}$ chwastami o czynniki środowiska, z powodu stosunkowo niewielkiej masy systemu korzeniowego i słabego pokrywania liśćmi powierzchni gleby. Al-Khatib (1994) na podstawie 25-letnich obserwacji podaje, że chwasty mogą obniżać plon cebul tulipanów o 36\%, irysów (kosaćców) o 38\% i narcyzów o $41 \%$. Wrażliwsze na zachwaszczenie mogą być rośliny uprawiane $\mathrm{z}$ małych cebul i bulw od roślin $\mathrm{z}$ cebul dużych, co stwierdzono w przypadku mieszańców lilii azjatyckich (Jagusz 1989a). Chwasty moga powodować zniekształcenia roślin. Może ulec zmianie struktura plonu. Lawson i Wieseman (1975) stwierdzili, że w uprawie tulipanów wynikiem konkurencji chwastów było zmniejszenie udziału cebul dużych. W narcyzach zachwaszczenie w początkowym okresie wzrostu powodowało szybsze zamieranie liści, rośliny słabiej kwitły i tworzyły mniejsze cebule pomimo likwidacji chwastów w drugiej połowie okresu wegetacyjnego (Lawson i Wieseman 1978). Dlatego, aby uniknąć negatywnego wpływu chwastów, plantacje roślin cebulowych powinny być wolne od chwastów przynajmniej od początku ukazywania się liści do kwitnienia. Opóźnienie pierwszego zabiegu istotnie ogranicza przyrost masy cebul. Może też zwiększać zagrożenie chorobami i szkodnikami. Skuteczna ochrona przed chwastami jest ważna zwłaszcza w uprawie na większych areałach i w produkcji materiału rozmnożeniowego oraz do pędzenia. Konieczne jest usuwanie chwastów zabiegami mechanicznymi i chemicznymi, pod warunkiem, że są dopuszczone do stosowania odpowiednie herbicydy selektywne w stosunku do wymienionych gatunków.

\section{Problem chwastów na plantacjach ozdobnych roślin cebulowych / Problem of weeds in ornamental bulbs plantations}

W systemach wspomagania decyzji o ochronie, monitoring chwastów polegający na dobrym rozpoznaniu składu gatunkowego flory segetalnej, występującej w różnych rejonach kraju, w zależności od rodzaju gleby i innych uwarunkowań agroekologicznych, stanowi podstawę opracowania skutecznych metod ograniczania konkurencji chwastów (Rola i wsp. 1999). Istotna jest też znajomość dynamiki pojawiania się poszczególnych taksonów w zależności od gatunku uprawianych roślin oraz terminów siewu lub sadzenia. W Polsce przeprowadzono wiele obserwacji nad rozmieszczeniem i występowaniem różnych gatunków chwastów w wielkoobszarowych roślinach rolniczych (Rola i wsp. 1999). Dla upraw małoobszarowych (warzywa, rośliny ozdobne) jest mniej udokumentowanych badań, chociaż w przypadku warzyw rozeznanie jest dość dobre (Dobrzański 1999; Siciński 2000). Na plantacjach roślin ozdobnych o stosunkowo małych powierzchniach i dużym rozproszeniu, obserwacje dotyczące występowania chwastów są nie- liczne. Do częściej spotykanych gatunków można zaliczyć: Echinochloa crus-galli, Galinsoga parviflora, Chenopodium album, Stellaria media, Amaranthus retroflexus, Capsella bursa-pastoris, Lamium amplexicaule, Matricaria maritima ssp. inodora, Polygonum ssp. Kłopotliwym chwastem jest Convonvulus arvensis (powój polny), który wraz ze wzrostem pędów kwiatostanowych oplata je do samego wierzchołka. Gatunki te są też najczęściej wymieniane w publikacjach polskich autorów (Jagusz 1989a; Hetman i Laskowska 1990a, b; Dobrzański i Gabarkiewicz 1993; Waźbińska i wsp. 1999), w których przedstawiono wyniki badań skuteczności biologicznej herbicydów.

Występowanie chwastów zależy od terminu sadzenia, a także stanowiska w zmianowaniu. Inny może być skład gatunkowy chwastów w roślinach sadzonych jesienią (np. tulipany), a nieco inny wiosną (np. mieczyki). W uprawie z jesiennego terminu sadzenia (np. tulipany, cebulica syberyjska) wyróżnia się dwa okresy pojawiania się chwastów: pierwszy - od sadzenia i wystąpienia pierwszego silnego mrozu do końca zimy; drugi - od wczesnej wiosny następnego roku, gdy chwasty kiełkują i wschodzą do czasu zbioru. Chwasty pojawiające się późną jesienią - po sadzeniu, nie stanowią większego zagrożenia pod warunkiem, że nie przezimują. Gdy jest długa i ciepła jesień, zanim nadejdą mrozy, mogą wzejść zimujące i ozime gatunki (np. C. bursa-pastoris, Thlaspi arvense, S. media, Galium aparine, Senecio vulgaris, taksony $\mathrm{z}$ rodzajów Lamium ssp., Anthemis ssp., Matricaria ssp.) zimujące w fazie rozetek liściowych. Mogą one wschodzić także wiosną, ponieważ cechują się szerokim zakresem temperatur wymaganych do kiełkowania (Markow 1978; Dobrzański 2009). Część chwastów wschodzących późną jesienią może wymarznąć, ale wiosną pojawiają się ponownie, szczególnie po pierwszym mechanicznym wzruszeniu międzyrzędzi. Jednak $\mathrm{w}$ niektórych latach obniżona temperatura jesienią po sadzeniu i późniejsze ocieplenie może spowodować kiełkowanie chwastów na przełomie listopada i grudnia. Gdy nie ma śniegu i zimą są okresowe ocieplenia, ich kiełkowanie i wschody można zaobserwować przez cały grudzień oraz w pierwszej i drugiej dekadzie stycznia. Jesienią po posadzeniu tulipanów i innych roślin może być trudne zniszczenie chwastów zabiegami mechanicznymi. Opady deszczu i wysoka wilgotność gleby, często występujące w tym czasie, utrudniają wprowadzenie na pole narzędzi. Niektóre chwasty mogą być nieznacznie uszkadzane przez mróz, ale po wiosennym ociepleniu natychmiast się regenerują. Zanim gleba po zimie przeschnie, do poziomu umożliwiającego wejście $\mathrm{w}$ pole $\mathrm{z}$ zabiegami mechanicznymi i ręcznym pieleniem, zdążą się silnie ukorzenić i stają się trudne do usunięcia. $\mathrm{Z}$ tego powodu producenci sięgają chętnie po herbicydy, które można aplikować jesienią po sadzeniu cebul lub wczesną wiosną, kiedy duża wilgotność gleby uniemożliwia uprawki międzyrzędowe i ręczne pielenie. Wczesną wiosną, oprócz wymienionych, szybko wschodzą inne gatunki kiełkujące $\mathrm{w}$ temperaturze poniżej $5^{\circ} \mathrm{C}$ (np. Ch. album, Fumaria officinalis, S. arvensis, Polygonum ssp., Fallopia convolvulus, Aethusa cynapium, G. pusillum, Urtica urens, Euphorbia helioscopia, Veronica ssp.). Większość z nich cechuje się ,szeroką amplitudą ekologiczną", czyli mogą wschodzić przez cały okres wegetacji 
(Lauer 1953; Markow 1978; Dobrzański 2009). Powszechnie spotykane ciepłolubne chwasty takie, jak: Galinsoga parviflora i Amranthus retroflexus w uprawie tulipanów zazwyczaj pojawiają się później i mogą silnie zachwaszczać plantację w okresie wykopywania cebul, ale gdy wiosną temperatura gleby przekracza $6-8^{\circ} \mathrm{C}$, a w kwietniu i na początku maja są dni z temperaturą około $20^{\circ} \mathrm{C}$, chwasty te masowo występują wcześniej. Mieczykom sadzonym wiosną od kwietnia do połowy maja, gdy bulwy są wykopywane od końca września do listopada, mogą towarzyszyć wszystkie wymienione gatunki przez cały okres wegetacji, przy czym największa ich ilość spotykana jest od kwietnia do czerwca. Później dynamika ich wyrastania jest wolniejsza. Z chwastów jednoliściennych występuje głównie Poa annua, czasami Avena fatua i gdy się ociepli dołącza do nich E. crus-galli, która najlepiej kiełkuje w temperaturze około $10^{\circ} \mathrm{C}$.

\section{Metody ochrony cebulowych roślin ozdobnych przed chwastami / Methods of protection of ornamental bulbs against weeds}

Każda technologia uprawy roślin powinna prowadzić do minimalizacji niszy ekologicznej niezbędnej dla rozwoju chwastów i dlatego w integrowanej ochronie przed chwastami mieści się szereg następujących po sobie zabiegów uprawowych i pielęgnacyjnych, przy czym koncepcja integrowanej ochrony nie wyklucza doraźnej aplikacji herbicydów w sytuacjach, kiedy jest to uzasadnione (Dobrzański i Adamczewski 2009). Jako jedną z metod do osłabienia wyrastania chwastów, oprócz mechanicznego odchwaszczania i ręcznego pielenia, można wykorzystywać martwe ściółki z materiałów organicznych, np. z kory, trocin, pociętej słomy. Taka metoda jest od dawna polecana w uprawach roślin cebulowych, zwłaszcza w tulipanach, liliach i mieczykach (Marcinkowski 1975; Grzeszkiewicz 1978; Wiśniewska-Grzeszkiewicz 1982; Grabowska i wsp. 1987; Koster i wsp. 1997). Hetman i Laskowska (1990a) wskazuja na pozytywny wpływ ściółkowania w uprawie cebulicy syberyjskiej. Jagusz (1989a) podaje, że w uprawie lilii jesienią ściółkowanej korą, wiosną ogólny stopień pokrycia gleby przez chwasty był około $50 \%$ mniejszy w porównaniu do uprawy bez ściółki. Jednak warstwa każdej ściółki organicznej z czasem staje się cieńsza i mogą przerastać przez nią niektóre gatunki chwastów (Ch. album, U. urens, E. repens). Ściółki mogą też przyspieszać pojawianie się ciepłolubnych gatunków (E. crus-galli i G. parviflora) oraz wzrost ich udziału w strukturze zachwaszczenia. W jednym $\mathrm{z}$ doświadczeń Jagusz (1989a) wykazał, że udział tych gatunków, w ogólnej liczbie chwastów, w liliach ściółkowanych był odpowiednio większy ponad dwu- i trzykrotnie. Przerastające przez ściółkę chwasty trudno jest zniszczyć uprawkami mechanicznymi. Według Kostera i wsp. (1997) w Holandii dobre wyniki w ograniczaniu zachwaszczenia uzyskano, gdy w roślinach cebulowych do zmianowania wprowadzano międzyplony $\mathrm{z}$ facelii lub gorczycy. Pomimo tego zwalczanie chwastów polega tam głównie na stosowaniu herbicydów.
Można polecać różne metody odchwaszczania, $\mathrm{z}$ chemicznymi włącznie. W Polsce wykonano wiele badań nad metodami zwalczania chwastów dostosowanymi do naszych warunków agroekologicznych i oceną skuteczności oraz fitotoksyczności różnych substancji czynnych w stosunku do ważniejszych gatunków ozdobnych roślin cebulowych uprawianych z cebul i bulw (Rolewska i Saniewski 1978; Rolewska i Mynett 1979; Hetman i wsp. 1984; Jagusz i Borowy 1984, 1988; Jagusz 1987, 1988, 1989a, b; Mynett i Jagusz 1987, 1990; Jagusz i Mynett 1988; Hetman i Laskowska 1990a, b; Gabarkiewicz 1995). Badania prowadzono głównie w Instytucie Sadownictwa i Kwiaciarstwa w Skierniewicach (obecnie Instytut Ogrodnictwa) oraz Akademii Rolniczej (obecnie Uniwersytet Przyrodniczy) w Lublinie. Oceniano skuteczność biologiczną i przydatność środków, które zawierały substancje czynne o szerokim spektrum działania przydatne do zwalczania chwastów jednorocznych dwuliściennych i jednoliściennych: chloroprofam, chlopyralid, izoksaben, lenacyl, linuron, pendimetalina, napropamid, metamitron, oksyfluorofen, fluorochloridon, metazachlor, mieszaniny pendimetaliny $\mathrm{z}$ metamitronem i linuronu $\mathrm{z}$ napropamidem. Oceniano też skuteczność powschodowych graminicydów (fluazyfop-P-butylowy, chizalofop-P-etylowy, chaloksyfop etoksyetylowy i cykloksydim), zwalczających roczne chwasty jednoliścienne i perz. Wykazano przydatność wymienionych substancji czynnych do zwalczania chwastów występujących w tej grupie roślin. Potwierdzono, że w naszych warunkach można je stosować w podobny sposób, jak w innych krajach. Są to znane od wielu lat herbicydy przebadane w uprawach rolniczych i warzywnych oraz zalecane do ochrony roślin ozdobnych (np. chloroprofam od ponad 50 lat) w wielu krajach (Torquand 1964; Lawson i Wieseman 1975, 1978; Fetvadjieva i Dinova 1980; Margraf i Albrecht 1990; Al-Khatib 1994, 1996; Kwon i wsp. 1996; Chastagner 1997; Gilareth i Bell 1998; Koster i wsp. 1999; Miller i Libbey 2000, 2012; Arora i wsp. 2002; Manuja i wsp. 2005; Richardson i Zandstra 2006; Marinangeli i wsp. 2010; Byrd 2013). Większość herbicydów zawierających wymienione substancje jest nadal dopuszczona we wszystkich państwach, gdzie ozdobne rośliny cebulowe są uprawiane. Richardson i Zandstra (2006) w uprawie mieczyków otrzymali pozytywne wyniki odchwaszczania flumioksazinem i mieszaniną tej substancji z s-metolachlorem. Antosik i wsp. (1997) wykazali, że pirydat, fenmedifam, mieszanina fenmedifamu $\mathrm{z}$ desmedifamem i etofumesatem stosowane po wschodach chwastów i trzech odmian tulipanów przed ich ogłowieniem nie wpływają na obniżenie plonu cebul. Natomiast oksyfluorofen stosowany w tym terminie był fitotoksyczny i obniżał istotnie plon. Miller i Libbey (2012) potwierdzili możliwość stosowania po posadzeniu tulipanów, irysów i narcyzów mieszanin różnych substancji czynnych, np. s-metolachloru z napropamidem. Najmniej badań wykonano nad reakcją krokusów. W dostępnej literaturze znaleziono tylko jedną publikację (Hetman i Laskowska 1990b), w której potwierdzono, że krokus reaguje podobnie na metamitron i lenacyl, jak inne rośliny cebulowe, ale najlepsze wyniki uzyskiwano po zastosowaniu fluorochloridonu. 


\section{Możliwości chemicznej ochrony w Polsce Possibilities of chemical protection in Poland}

Ochrona roślin ozdobnych uprawianych na dużych plantacjach bez stosowania herbicydów jest wprawdzie możliwa, lecz trudna i kosztowna. We wszystkich krajach, gdzie produkcja tych roślin jest prowadzona na skalę towarową, herbicydy są zalecane i wykorzystywane w praktyce. Tak było też w Polsce, ale obecnie sytuacja wyraźnie się zmieniła.

Plantatorzy korzystający $\mathrm{z}$ różnych aktualnych programów ochrony roślin ozdobnych (np. Zalecenia 2012-2013) zauważają, że nie można w nich odnaleźć wielu herbicydów. Jest to następstwem wprowadzonych kilka lat temu regulacji prawnych dotyczących rejestracji środków ochrony roślin, które spowodowały wiele ograniczeń. Producenci środków ochrony roślin zostali zobowiązani do przedstawienia nowej dokumentacji badawczej, zgodnej z obecnie przyjętymi procedurami, aby otrzymać nowe zezwolenie na wprowadzenie środka do handlu. Dotyczyło to wszystkich środków i zastosowań, również herbicydów od dawna zalecanych $\mathrm{w}$ roślinach ozdobnych. W daleko idącym uproszczeniu oznacza to, że zażądano nowych wyników badań, które powinny być przeprowadzone na koszt producenta środka, potwierdzających skuteczność preparatów stosowanych nawet od kilkudziesięciu lat, sprawdzonych $\mathrm{w}$ praktyce i nadal używanych w krajach sąsiednich. Bezpośrednim użytkownikom środków działanie takie wydać się może nielogiczne. Niektórzy pracownicy naukowi podkreślają, że powtórne badanie tego, co już zostało udowodnione, jest niecelowe.

Wykonanie badań skuteczności w roślinach o bardziej skomplikowanej technologii uprawy w porównaniu np. ze zbożami, a nawet niektórymi warzywami, jest technicznie bardziej uciążliwe i wielokrotnie droższe. Stąd niełatwo znaleźć chętnych do ich sfinansowania. Efektem tego jest wykreślenie $\mathrm{z}$ etykiet-instrukcji stosowania wielu gatunków, przy okazji wznawiania rejestracji, co często jest równoznaczne $z$ brakiem realnej szansy ochrony. $\mathrm{Na}$ deficyt herbicydów dla upraw małoobszarowych i na implikacje, jakie z tego wynikają dla praktyki, zwrócono już wcześniej uwagę (Adamczewski i wsp. 2006; Dobrzański i Anyszka 2006; Matyjaszczyk 2012). Możliwości i perspektywy ochrony roślin ozdobnych omawiają Łabanowski i wsp. (2011) w nawiązaniu do przepisów Rozporządzenia Parlamentu Europejskiego i Rady (2009).

Ogólna powierzchnia uprawy roślin ozdobnych nie jest wielka i zaliczana jest do tzw. ,upraw małoobszarowych”. Nie wpływają one znacząco na sprzedaż środków, a koszt doświadczeń polowych $\mathrm{z}$ herbicydami $\mathrm{w}$ roślinach ozdobnych jest znacznie wyższy i przeprowadzenie badań jest trudniejsze niż w większości roślin rolniczych, a nawet warzywnych. Dlatego producenci środków ochrony roślin rzadko są zainteresowani rejestracją nowych herbicydów dla upraw małoobszarowych i rezygnuja $z$ prowadzenia i finansowania badań ze starymi, dobrze znanymi i sprawdzonymi w praktyce środkami, w celu uzyskania dla nich nowych zezwoleń. Efektem tego jest wykreślenie niektórych gatunków roślin, głównie ozdobnych i warzyw z etykiet-instrukcji stosowania środków. Jako wythumaczenie przyczyn zawężania zakresów stosowania etykiet w Polsce podaje się, że mają one miejsce $\mathrm{z}$ powodu wdrażania nowych, unijnych przepisów dotyczących ochrony roślin i wzrostu wymagań rejestracyjnych, co jest prawda, ale nie tłumaczącą dlaczego w wielu innych państwach członkowskich (gdzie przepisy unijne również obowiązują) pewne możliwości chemicznej ochrony są dostępne, ale nie w Polsce. Dotychczasowe przepisy polskie w zbyt małym stopniu uwzględniały sytuacje wyjątkowe, w tym ochronę upraw małoobszarowych, podczas gdy praktyka w tzw. ,starych państwach członkowskich" była całkiem inna - bardziej pragmatyczna i przyjazna producentom rolnym.

Warto przytoczyć, jakie substancje czynne herbicydów, były u nas zalecane $\mathrm{w}$ programach ochrony roślin na lata 2008-2009, aby uzmysłowić, że niektóre z nich są nadal zalecane w innych krajach, gdzie technologie uprawy roślin ozdobnych są podobne do polskich. Pendimetaliną tylko w formie środka Stomp 330 EC (4 1/ha) można było odchwaszczać wiosną - przed wschodami lilie, mieczyki w 4-10 dni po sadzeniu bulw i tulipany ( $31 /$ ha $)$ - po sadzeniu jesienia, przed mrozami. Termin stosowania środka upłynął 31.07.2012 r. Herbicyd ten otrzymał nowe zezwolenie Ministerstwa Rolnictwa i Rozwoju Wsi (MRiRW) nr R-75/2010 z dnia 08.10.2010 r. nieuwzględniające roślin ozdobnych. W handlu może być kilka środków zawierających pendimetalinę, ale w odróżnieniu od innych krajów nie można ich u nas zalecać do ochrony tej grupy roślin. Metamitron (Goltix $70 \mathrm{WG}$ w dawce $4 \mathrm{~kg} / \mathrm{ha}$ ) był polecany w liliach, w fazie wschodów i po wschodach; w mieczykach po wschodach (3 kg/ha), w narcyzach w kilka dni po zbiorze kwiatów i ogłowieniu (4 kg/ha). W Polsce jest zarejestrowanych kilka środków ochrony roślin zawierających metamitron, ale $w$ ich etykietach rośliny ozdobne nie są wymieniane. Linuron w formie środków Afalon 50 WP i Linurex 50 WP (1-1,5 kg/ha) zalecano po posadzeniu mieczyków. Obecnie te preparaty nie są zalecane w żadnej roślinie uprawianej. Ta sama substancja czynna w formie preparatu Afalon Dyspersyjny 450 SC była zalecana po wschodach mieczyków. Przy okazji wznowienia rejestracji mieczyki usunięto $\mathrm{z}$ etykiety według zezwolenia MRiRW nr R-57/2010 z dnia 16.06.2010 r. Ostatnio zarejestrowano kilka preparatów zawierających linuron posiadających taką samą ilość substancji czynnej jak Afalon Dyspersyjny $450 \mathrm{SC}$, ale w ich etykietach mieczyki nie są wymienione. Lenacyl (Venzar 80 WP, Buracyl 80 WP) zalecano do ochrony tulipanów jesienią na około 2 tygodnie po sadzeniu (1,2-2 kg/ha) lub wczesną wiosna (1-1,5 kg/ha). Chloroprofam w formie środka Aliacine $400 \mathrm{EC}$ do roku 2011 był zalecany głównie do ochrony cebuli jadalnej, ale można było go stosować w uprawie narcyzów, lilii wiosną po rozmarznięciu gleby $\mathrm{i}$ w mieczykach wiosną po sadzeniu, przed rozwinięciem się liści, a także w nasadzeniach tulipana jesienią $\mathrm{w}$ miesiąc po sadzeniu cebul (4-6 1/ha). Środek utracił ważność zezwolenia. Jego rejestracja jest obecnie wznawiana, ale tylko do ochrony cebuli jadalnej. W etykiecie analogicznego środka Criptic 400 EC jest wymieniona tylko cebula jadalna uprawiana z siewu. Herbicydy pod różnymi nazwami zawierające tę substancję czynną są zalecane w cebulowych roślinach ozdobnych w wielu krajach i prawdopodobnie nigdzie, 
poza Polską, roślin ozdobnych $\mathrm{z}$ etykiet nie wykreślono. Chlopyralid w formie środka Lontrel 300 SL można było stosować wiosną po wschodach lilii i w narcyzach wiosna, około 7 dni po zbiorze kwiatów (0,3 1/ha). Ostateczny termin stosowania upłynął 01.07.2012 r. Po wznowieniu rejestracji, w jego etykiecie według zezwolenia MRiRW nr R-88/2010 z dnia 15.12.2010 r. nie wymieniono roślin ozdobnych. Herbicyd ten zwalcza między innymi: ostrożeń polny, chwasty rumianowate, żółtlicę drobnokwiatowa i rdesty. Do zwalczania perzu i rocznych chwastów jednoliściennych jeszcze w latach 2008-2009 można było stosować tylko jeden graminicyd haloksyfop-R (Perenal 104 EC). Środek ten utracił ważność zezwolenia na aplikację we wszystkich uprawianych u nas roślinach, z ozdobnymi włącznie. Obecnie żadnego graminicydu zalecanego $\mathrm{w}$ innych uprawach nie można u nas zalecać i stosować $\mathrm{w}$ roślinach ozdobnych. W przypadku silnego zachwaszczenia perzem i rocznymi chwastami jednoliściennymi nie jest zabronione pracochłonne ręczne pielenie i zabiegi mechaniczne.

\section{Jak jest $w$ innych krajach? / How it is in other countries?}

Analizę możliwości ochrony poszczególnych gatunków cebulowych roślin ozdobnych przeprowadzono $\mathrm{w}$ oparciu o zapisy podane w etykietach-instrukcjach obowiązujących w końcu roku 2011 do lutego 2013 (Everest 2011; Bloembollenbericht 2012; Miller 2012; PflanzenschutzmittelVerzeichnis 2012; Ctgb. Pesticides database 2013; Cultures florales 2013; The Pesticides Register Database 2013) oraz zalecenia na rok 2012 i 2013 przyjęte w różnych krajach. Korzystano też z informacji podanych w wyszukiwarkach środków, znajdujących się na stronach internetowych organów odpowiedzialnych za rejestrację oraz z europejskiej bazy danych o pestycydach (ec.europa. eu/sanco_pesticides/public/index.cfm). Uzyskane informacje przedstawia tabela 1., w której podano tylko substancje czynne, bez liczby preparatów handlowych i form użytkowych oraz środków zawierających glifosat używanych głównie do zwalczania perzu i innych chwastów $\mathrm{w}$ zespole uprawek poprzedzających sadzenie cebul lub bulw, lub przed wschodami, zanim z cebul ukażą się liście. Na przykład $\mathrm{w}$ Niemczech według stanu na 13.02.2013 r. dopuszczone jest stosowanie włącznie ze środkami zawierającymi glifosat 88 środków, w tym 3 środki zawierające fenmedifam i 2 zawierające prosulfurokarb oraz 2 środki zawierające metazachlor (nigdy u nas niedopuszczone), 2 zawierające pendimetalinę. Cebule jadalną o podobnej technologii uprawy, jak ozdobne rośliny cebulowe, można odchwaszczać środkiem zawierającym oksyfluorofen. Należy sądzić, że ozdobne rośliny cebulowe, z wyjątkiem tulipanów, powinny reagować

Tabela 1. Substancje czynne herbicydów zarejestrowane do ochrony ozdobnych roślin cebulowych w różnych krajach Table 1. Active substances of herbicides authorized in different countries for weed management in ornamental bulbs

\begin{tabular}{|c|c|c|}
\hline Kraj-Country & Substancja czynna - Active substance & Gatunki - Species \\
\hline 1 & 2 & 3 \\
\hline \multicolumn{3}{|c|}{$\begin{array}{l}\text { Kraje Unii Europejskiej w obrębie centralnej strefy rejestracyjnej (do której należy Polska) } \\
\text { European Union countries in the central registration zone (among others Poland) }\end{array}$} \\
\hline $\begin{array}{l}\text { Holandia } \\
\text { Holland }\end{array}$ & $\begin{array}{l}\text { quizalofop-P-ethyl } \\
\text { chlorpropham } \\
\text { chloridazon } \\
\text { chloridazon, } \\
\text { mixtures of chloropropham } \\
\text { dimethenamid-P } \\
\text { phenmedipham } \\
\text { linuron } \\
\text { metamitron } \\
\text { pendimethalin } \\
\text { pendimethalin }+ \text { linuron }+ \text { glyphosate } \\
\text { s-metolachlor } \\
\text { mixture of s-metolachlor }+ \text { chloridazon } \\
+ \text { dimethenamid-P } \\
\text { tepraloxydim }\end{array}$ & $\begin{array}{l}\text { wszystkie uprawiane z cebul z wyjątkiem tulipana } \\
\text { all ornamental bulbs with the exception of tulip } \\
\text { tulipany, mieczyki, narcyzy, kosaćce, krokusy, } \\
\text { konwalie, cebulica, czosnek ozdobny i inne } \\
\text { tulips, gladiolus, narcissus, iris, crocus, } \\
\text { lilies of the valley, scilla, ornamental garlic and others } \\
\text { wszystkie uprawiane z cebul i bulw } \\
\text { all ornamental bulbs } \\
\text { tulipany, narcyzy, kosaćce, lilie } \\
\text { tulips, narcissus, iris, lilies } \\
\text { tulipany - tulips } \\
\text { kosaćce - iris } \\
\text { mieczyki, hiacynty - gladiolus, hyacinths } \\
\text { tulipany, lilie, narcyzy, kosaćce } \\
\text { tulips, lilie, narcissus, iris } \\
\text { wszystkie uprawiane z cebul i bulw } \\
\text { all ornamental bulbs } \\
\text { mieczyki - gladiolus } \\
\text { lilie, tulipany - lilie, tulips } \\
\text { tulipany - tulips } \\
\text { hiacynty, narcyzy, mieczyki, tulipany } \\
\text { hyacinths, narcissus, gladiolus, tulips }\end{array}$ \\
\hline
\end{tabular}




\begin{tabular}{|c|c|c|}
\hline 1 & 2 & 3 \\
\hline $\begin{array}{l}\text { Niemcy } \\
\text { Germany }\end{array}$ & $\begin{array}{l}\text { quizalofop-P-ethyl } \\
\text { cycloxydim } \\
\text { dimethenamid-P } \\
\text { metazachlor + dimethenamid-P + pethoxamid } \\
\text { phenmedipham } \\
\text { pelargonic acid } \\
\text { metazachlor } \\
\text { pendimethalin } \\
\text { prosulfocarb }\end{array}$ & $\begin{array}{l}\text { mieczyki, lilie, tulipany } \mathrm{i} \text { inne rośliny ozdobne } \\
\text { gladiolus, lilie, tulips and other ornamental plants }\end{array}$ \\
\hline $\begin{array}{l}\text { Republika Czeska } \\
\text { Czech Republic }\end{array}$ & $\begin{array}{l}\text { clopyralid } \\
\text { metamitron }\end{array}$ & $\begin{array}{l}\text { mieczyki - gladiolus } \\
\text { tulipany, narcyzy, mieczyki } \\
\text { tulips, narcissus, gladiolus }\end{array}$ \\
\hline $\begin{array}{l}\text { Irlandia } \\
\text { Ireland }\end{array}$ & $\begin{array}{l}\text { chlorpropham } \\
\text { linuron }\end{array}$ & wszystkie gatunki cebulowe - all bulbs species \\
\hline $\begin{array}{l}\text { Wielka Brytania } \\
\text { Great Britain }\end{array}$ & $\begin{array}{l}\text { pendimethalin } \\
\text { pendimethalin }+ \text { dimethenamid-P }\end{array}$ & $\begin{array}{l}\text { narcyzy - rejestracja pozaetykietowa } \\
\text { narcissus - off-label registration } \\
\text { różne gatunki ozdobnych roślin cebulowych } \\
\text { rejestracja pozaetykietowa } \\
\text { different species of ornamental bulbs - off-label } \\
\text { registration }\end{array}$ \\
\hline $\begin{array}{l}\text { Austria } \\
\text { Austria }\end{array}$ & linuron & mieczyki, hiacynty - gladiolus, hyacinths \\
\hline \multicolumn{3}{|c|}{ Niektóre inne kraje europejskie - Some other European countries } \\
\hline $\begin{array}{l}\text { Francja } \\
\text { France }\end{array}$ & $\begin{array}{l}\text { chlorpropham } \\
\text { chloridazon } \\
\text { isoxaben } \\
\text { cycloxydim } \\
\text { chlorpropham } \\
\text { isoxaben } \\
\text { quizalofop-P-ethyl }\end{array}$ & $\begin{array}{l}\text { tulipany - tulips } \\
\text { mieczyki - gladiolus }\end{array}$ \\
\hline $\begin{array}{l}\text { Szwajcaria } \\
\text { Switzerland } \\
\end{array}$ & linuron & $\begin{array}{l}\text { hiacynty, mieczyki, tulipany } \\
\text { hyacinths, gladiolus, tulips }\end{array}$ \\
\hline \multicolumn{3}{|c|}{ Niektóre kraje spoza Europy - Some countries outside Europe } \\
\hline $\begin{array}{l}\text { Stany Zjednoczone } \\
\text { Ameryki Północnej } \\
\text { USA }\end{array}$ & $\begin{array}{l}\text { napropamide } \\
\text { pendimethalin } \\
\text { s-metolachlor } \\
\text { fenoxaprop } \\
\text { clethodim } \\
\text { dimethenamid-P } \\
\text { isoxaben }\end{array}$ & $\begin{array}{l}\text { narcyzy, lilie, kosaćce, tulipany } \\
\text { narcissus, lilies, iris, tulips } \\
\text { mieczyki, narcyzy, lilie, kosaćce, tulipany } \\
\text { gladiolus, narcissus, lilie, iris, tulips } \\
\text { kosaćce - iris } \\
\text { kosaćce, narcyzy, tulipany } \\
\text { iris, narcissus, tulips }\end{array}$ \\
\hline $\begin{array}{l}\text { Australia } \\
\text { Australia }\end{array}$ & chloridazon & $\begin{array}{l}\text { lilie, tulipany, mieczyki, narcyzy, kosaćce } \\
\text { lilie, tulips, gladiolus, narcissus, iris }\end{array}$ \\
\hline
\end{tabular}

podobnie na ten herbicyd jak cebula, dlatego w informacjach technicznych środków, zawierających tę substancję czynną, są zalecenia jego stosowania w mieczykach i kosaćcach po posadzeniu, ale przed wschodami (http://www.ma-industries.com). Jednak w zaleceniach niemieckich i holenderskich herbicydy zawierające oksyfluorofen nie są wymieniane.

Poszczególne kraje różnią się asortymentem zalecanych środków i w niektórych zalecenia obejmują tylko 1-2 gatunki, ponieważ nie we wszystkich krajach rośliny ozdobne uprawiane $\mathrm{z}$ cebul i bulw mają znaczenie gospodarcze. Są też rozbieżności odnośnie reakcji niektórych gatunków. Howard i wsp. (1990) podają, że zalecany w niektórych krajach izoksaben może powodować uszkodzenia. Być może, $\mathrm{z}$ tego powodu nie jest wymieniany w zaleceniach holenderskich i niemieckich.

W świetle tego wykazu można postawić pytanie, w jaki sposób w innych państwach Unii Europejskiej, gdzie herbicydy w roślinach ozdobnych są wykorzystywane, np. w Holandii, rozwiązano problem przeprowadzania nowych badań skuteczności od dawna znanych herbicydów uzasadniające ich utrzymanie w zaleceniach, tak jak tego zażądano w Polsce.

W wielu państwach wypracowano własne, pragmatyczne sposoby radzenia sobie $\mathrm{z}$ problemem, między innymi:

1. Wczesne rozpoczęcie działania zespołów do spraw poszczególnych upraw małoobszarowych. Zespoły te 
skupiały przedstawicieli producentów, naukowców oraz organów rejestrujących i poprzez wczesne sygnalizowanie problemów oraz wykorzystanie wszystkich dostępnych wyników badań, doprowadziły do utrzymania wielu upraw w etykietach.

2. Uznawanie dla celów rejestracyjnych także niektórych badań wykonanych dawniej, nie zawsze odpowiadających obecnym kryteriom, w oparciu o fakt, że ich wyniki zostały potwierdzone $\mathrm{w}$ praktyce np. „large farmer trials" (doświadczenia produkcyjne).

3. Utworzenie funduszy państwowych dofinansowujących badania skuteczności środków ochrony roślin dla ważnych gospodarczo roślin małoobszarowych.

4. Prężne działanie organizacji rolniczych zrzeszających producentów upraw małoobszarowych, które skutecznie lobbowały na rzecz utrzymania pewnych zastosowań przed ich wycofaniem.

5. Bardzo szerokie (dużo szersze niż w Polsce) korzystanie $\mathrm{z}$ rejestracji pozaetykietowej, zwanej także rejestracją off-label. Rejestracja taka daje możliwość legalnego korzystania ze środka, przy uproszczonej procedurze rejestracyjnej. Zdejmuje jednak $\mathrm{z}$ producenta środka ciężar odpowiedzialności za skuteczność i fitotoksyczność względem roślin uprawnych.

Wprawdzie usunięto wiele środków, których substancje czynne nie znalazły się w załączniku do Dyrektywy 91/414 EEC (1991), ale w tych, które zostały włączone, nie można dostrzec, aby w jakimkolwiek kraju, z wyjątkiem naszego, rośliny ozdobne zostały pominięte.

\section{Podsumowanie / Summation}

Powierzchnia roślin ozdobnych jest mała (około 2,5 tys. ha), ale są gospodarstwa uprawiające tulipany i mieczyki, nawet na kilku hektarach. Wartość produkcji z 1 hektara roślin ozdobnych wielokrotnie przewyższa wartość plonów zbóż i innych roślin rolniczych. Stąd straty ekonomiczne wywołane zachwaszczeniem moga być większe. Należy także podkreślić, że w obliczu braku odpowiednich środków chemicznych w Polsce i ich dobrej dostępności dla gospodarstw produkujących rośliny ozdobne w innych państwach członkowskich, nasi producenci mają gorszą pozycję w konkurowaniu na wspólnym rynku. Plantatorzy roślin ozdobnych wyjeżdżają do Holandii i innych państw w celu zapoznawania się $\mathrm{z}$ metodami produkcji. Korzystają też z porad doradców zagranicznych i ogólnie dostępnych zaleceń przyjętych w innych krajach.

Obawa przed poważnymi stratami ekonomicznymi może skłaniać niektórych producentów roślin ozdobnych do sięgania po herbicydy $\mathrm{z}$ naruszeniem obowiązującego prawa, będąc świadomymi, że produkują rośliny nieprzeznaczone do konsumpcji.
Jakie działania powinny zostać podjęte, aby poprawić obecną sytuację? Przepisy Unii Europejskiej umożliwiają tzw. rejestrację strefową, czyli dopuszczanie do stosowania środków zalecanych w innych krajach zaliczanych do tej samej strefy rejestracyjnej, nawet bez konieczności prowadzenia doświadczeń polowych, szczególnie, gdy dotyczą one znanych i od dawna stosowanych w innych krajach substancji. Polska należy do tej samej strefy, co Holandia, Niemcy, Wielka Brytania, Czechy. Dlatego należałoby się postarać o rejestrację strefową herbicydów zalecanych w tych krajach, zwłaszcza w Holandii i w Niemczech. Powinno to dotyczyć szczególnie herbicydów, które były już u nas zalecane i zawierających takie substancje czynne, jak: pendimetalina, chloroprofam, metamitron, linuron, niektóre graminicydy. Tym bardziej, że z tymi środkami, w różnych jednostkach badawczych, przeprowadzono $\mathrm{u}$ nas wiele lat temu badania skuteczności.

Polskie prawo umożliwia rozszerzenie rejestracji środka ochrony roślin (na mocy zezwolenia Ministra Rolnictwa i Rozwoju Wsi) o zastosowanie w uprawach nieobjętych rejestracją, uzyskaną przez producenta lub dystrybutora środka. Informacje te można wykorzystać do tzw. rejestracji pozaetykietowej (off-label), uwzględniającej rośliny ozdobne. Zgodnie z unijnym Rozporządzeniem 1107/2009 (2009), z wnioskiem o wydanie takiego zezwolenia moga występować instytucje państwowe, placówki naukowe i społeczno-zawodowe organizacje rolników, izby rolnicze, producenci środków ochrony roślin, a nawet każdy producent zajmujący się uprawą roślin. Nie wszyscy do tego upoważnieni o tym pamiętają i stąd nie podejmują żadnych działań. Nie jest też wykluczone, iż upoważnieni do tego ze względu na małą powierzchnię, brak osobistego zainteresowania i procedurę administracyjną zainteresowani wolą $\mathrm{z}$ takimi wnioskami nie występować. Producenci środków koncentrują się na uzyskaniu zezwolenia na stosowanie w jakiejkolwiek uprawie wielkoobszarowej oraz wprowadzeniu środka do handlu.

Należy zachęcać zrzeszenia producentów rolnych do występowania $\mathrm{z}$ wnioskiem o rejestrację pozaetykietową. Firmy agrochemiczne uwzględniające rośliny małoobszarowe $\mathrm{w}$ swoich etykietach, zgodnie $\mathrm{z}$ nowymi przepisami, będą miały zachęty w postaci wydłużenia okresu rejestracji środków. Ministerstwo Rolnictwa i Rozwoju Wsi spowodowało, że proces uzyskiwania zezwolenia na rejestrację off-label jest obecnie w Polsce nieco bardziej przyjazny i szybszy niż przed laty.

Jedynym satysfakcjonującym rozwiązaniem $\mathrm{z}$ punktu widzenia producentów roślin ozdobnych, a także z punktu widzenia interesu gospodarczego Polski, jako producenta tych roślin, jest umożliwienie dostępu do legalnej ochrony chemicznej. Sankcje w postaci mandatów nie rozwiążą sprawy i nie zapobiegną skutecznie stosowaniu niezarejestrowanych środków.

\section{Literatura / References}

Adamczewski K., Gusowski B., Matyjaszczyk E. 2006. Małoobszarowe uprawy rolnicze a chemiczna ochrona roślin. [Chemical plant protection in minor agricultural crops]. Prog. Plant. Prot./Post. Ochr. Roślin 46 (1): 55-62. 
Al-Khatib K. 1994. Weed Control in Ornamental Bulbs (Iris, Narcissi, Tulip). Western Washington Weed Control Guide. EB1791, 4 pp. http://cru.cahe.wsu.edu/CEPublications/eb1791/eb1791.html, accessed: 24.02.2013.

Al-Khatib K. 1996. Tulip (Tulipa spp.), daffodil (Narcissus spp.), and iris (Iris spp.) response to preemergence herbicides. Weed Technol. 10 (4): 710-715.

Antosik R., Orlikowski L.B., Dobrzański A. 1997. Herbicydy nalistne w zwalczaniu chwastów w uprawie tulipanów. s. 67-71. W: VII Ogólnopolski zjazd Hodowców Roślin Ogrodniczych. AR Szczecin, 11-13 września 1997, 432 ss.

Arora J.S., Kushal S., Kundra H.C., Singh K., Mishra R.L., Sanyat M. 2002. Effect of preemergence herbicides in gladiolus plantings. Floriculture research trend in India. p. 122-125. In: Proceedings of the National Symposium on Indian Floriculture in the new millennium. LalBagh, Bangalore, 25-27 February 2002, 189 ss.

Bloembollenbericht, nummer 3, 2012. Tulp, gladiool. http://www.agrotheek.nl/userfiles/file/235/Bloembollenbericht\%203\%2010-052012.pdf, accessed: 24.02.2013.

Byrd J.D. 2013. Weed Control Guidelines for Mississippi. Mississippi State University Extension Service. Publication 1532,250 pp.

Chastagner G.A. 1997. Pesticide use patterns associated with the production of ornamental bulb crops in the Pacific Northwest. Acta Hort. (ISHS) 430: 661-668.

Ctgb. Pesticides database. http://www.ctb-wageningen.nl/, accessed: 24.02.2013.

Cultures florales diverses - Desherbage 2013.http://e-phy.agriculture.gouv.fr/usa/17405901.htm., accessed: 24.02.2013.

Dobrzański A. 2009. Ekspertyza - Biologiczne i agrotechniczne aspekty regulowania zachwaszczenia. Sieć Naukowa „Agroinżynieria dla rozwoju zrównoważonego rolnictwa, przemysłu rolno-spożywczego i obszarów wiejskich - AgEngPol”, 24 ss. http://www.ageng pol.pl, dostęp: 24.02.2013.

Dobrzański A., Adamczewski K. 2009. Ekspertyza - Niechemiczne metody zwalczania chwastów - stan obecny i perspektywy. Sieć Naukowa „Agroinżynieria dla rozwoju zrównoważonego rolnictwa, przemysłu rolno-spożywczego i obszarów wiejskich AgEngPol", 29 ss. http://www.agengpol.pl, dostęp: 24.02.2013.

Dobrzański A., Anyszka Z. 2006. Problem braku odpowiednich herbicydów dla warzyw jako upraw małoobszarowych - implikacje dla praktyki. [The problem of shortage of suitable herbicides for vegetables as a minor crops - implication for the practice]. Prog. Plant. Prot./Post. Ochr. Roślin 46 (1): 63-70.

Dobrzański A., Gabarkiewicz R. 1993. Najważniejsze gatunki chwastów w uprawie roślin ozdobnych jednorocznych oraz szkółek krzewów i drzew ozdobnych. s. 105-107. W: Materiały 14. Spotkania Zesp. Herb. Kom. Nauk Ogrod. PAN, Lublin, 16-17 wrzesień 1993. Wyd. ART Olsztyn, 135 ss.

Dobrzański A. 1999. Chwasty w uprawach warzywnych - aktualne problemy i zagrożenia. s. 11-14. W: Przenikanie gatunków ruderalnych z siedlisk sadowniczych i parkowych do zbiorowisk segetalnych, upraw warzywniczych i rolniczych. XXIII Krajowa Konf. Naukowa z cyklu: „Rejonizacja chwastów segetalnych w Polsce”. Instytut Warzywnictwa, Skierniewice, 15-16 lipiec 1999, 68 ss.

Dyrektywa Rady z dnia 15 lipca 1991 roku nr 91/414/EWG dotycząca wprowadzania do obrotu środków ochrony roślin.

Europejska baza danych o pestycydach. 2013. ec.europa.eu/sanco_pesticides/public/index.cfm, dostęp: 24.02.2013.

Everest J.W. 2011. Homeowner trees and ornamentals weed control recommendations for 2011. IPM-0854. Alabama Cooperative Extension System, 12 pp.

Fetvadjieva N.A., Dinova M.S. 1980. Chemical weed control in the growing of gladiolus minibulbs (cormels). Acta Hort. (ISHS) 109: $333-342$.

Gabarkiewicz R. 1995. Wpływ Ramrodu Flo 480 SC na wzrost i plonowanie mieczyków. s. 106-110. W: Materiały z 15. Spotkania Zesp. Herb. Kom. Nauk Ogrod. PAN, Warszawa, 12 czerwca 1995. Wyd. ART Olsztyn, 153 ss.

Gilareth J.P., Bell M.L. 1998. Chemical weed control in gladiolus. Proc. Fla. State Hort Sci. 111: 29-32.

Grabowska B., Krause J., Mynett K. 1987. Uprawa cebulowych i bulwiastych roślin ozdobnych. PWRiL, Warszawa: 5-6, 8-11.

Grzeszkiewicz H. 1978. The effect of using composed pine bark for mulching on growth, flowering and crops of gladiolus (Gladiolus $\times$ hybridus grandiflorus). Acta Hort. (ISHS) 82: 37-42.

Hetman J., Laskowska H. 1990a. Stosowanie herbicydów i ściółek w uprawie cebulicy syberyjskiej. s. 74-75. W: Materiały z 17. Spotkania Zesp. Herb. Kom. Nauk Ogrod. PAN, Skierniewice, 13 czerwca 1990. Wyd. ART Olsztyn, 114 ss.

Hetman J., Laskowska H. 1990b. An evaluation of herbicides for field cultivation of crocus. Acta Hort. (ISHS) 325: 815-820.

Hetman J., Laskowska H., Borowy A. 1984. Porównanie wrażliwości ośmiu odmian tulipanów na Devrinol 50 WP, Dymid 80 W, Sencor i Venzar. s. 77-80. Materiały z 6. Spotkania Zesp. Herb. Kom. Nauk Ogrod. PAN, Warszawa - Skierniewice - Olsztyn, 22 czerwca 1984, 83 ss.

Howard S.W., Libbey C.R., Hall E.R. 1990. Herbicide evaluation in bulbous iris, narcissus, and tulip. Acta Hort. (ISHS) 266: 561-568.

Jagusz M. 1987. Zastosowanie powschodowych graminicydów w uprawie mieczyków ogrodowych. s. 69-72. W: Materiały z IX Spotkania Zesp. Herb. Kom. Nauk Ogrod. PAN, Lublin, 16 czerwca 1987. Wyd. ART Olsztyn, 78 ss.

Jagusz M. 1988. Przydatności herbicydu Stomp 330 EC do zwalczania rocznych chwastów jednoliściennych w uprawie tulipanów. s. 88-91. W: Materiały z 10. Spotkania Spotkania Zesp. Herb. Kom. Nauk Ogrod. PAN, Skierniewice, 14 czerwca 1988. Wyd. ART Olsztyn, 105 ss.

Jagusz M. 1989a. Wpływ wybranych herbicydów na wzrost i rozwój mieszańców azjatyckich lilii. Praca doktorska. Instytut Sadownictwa i Kwiaciarstwa, Skierniewice, 79 ss.

Jagusz M. 1989b. Wpływ wybranych herbicydów na plonowanie trzech odmian lilii. s. 88-91. W: Materiały z 10. Spotkania Zesp. Herb. Kom. Nauk Ogrod. PAN, Elblagg, 14 czerwca 1989. Wyd. ART Olsztyn, 134 ss.

Jagusz M., Borowy A. 1984. Ocena przydatności preparatów Devrinol 50 WP, Dual 720 EC, Lasso oraz Satecid 65 WP do zwalczania chwastów w uprawie mieczyków. s. 82-86. W: Materiały 6. Spotkania Zesp. Herb. Kom. Nauk Ogrod. PAN, Skierniewice, 22 czerwca 1984. Wyd. ART Olsztyn, 87 ss.

Jagusz M., Borowy A. 1988. Chemiczne zwalczanie rocznych chwastów jednoliściennych w uprawie mieczyków. [The chemical control on annual grass weeds in gladiolous cultivation]. Prace Inst. Sad., Seria B (12): 145-151.

Jagusz M., Mynett M. 1988. Reakcja mieczyków uprawianych bulw różnej wielkości na wybrane herbicydy. s. 92-97. W: Materiały z 10. Spotkania Zesp. Herb. Kom. Nauk Ogrod. PAN, Skierniewice, 14 czerwca 1988. Wyd. ART Olsztyn, 105 ss. 
Koster A.T.J., de Jong K.Y., Schouten E.T.J. 1999. Combinatie asulam en metamitron verbetert onkruidbestrijding: tulp, hyacint en lelie. Bloembollencultuur 110 (3): 38-39.

Koster A.T.J., van der Meer L.J., de Jong K.Y., van Haaster A.J.M., Kok B.J., van Aanholt J.T.M. 1997. Strategies for effective weed control in the future. Acta Hort. (ISHS) 430: 669-676.

Kwon O.D., Kim H.J., Kim J.K., Han K.P. 1996. Herbicide evaluation for preemergence weed control under various cropping patterns in gladiolus. RDA J. Agric. Sci. Crop Prot. 38 (1): 495-500.

Łabanowski G., Orlikowski L., Matysiak B. 2011. Aktualne możliwości i perspektywy ochrony roślin ozdobnych przed chorobami, szkodnikami i chwastami. Wybrane zagadnienia rejestracji środków ochrony roślin myśl przepisów rozporządzenia Parlamentu Europejskiego i Rady 1107/2009. Inst. Ochr. Roślin - PIB, Poznań, 17-18 październik 2011. http://www.ior.poznan.pl, dostęp: 24.02.2013.

Lauer E. 1953. Über die Keimtemperatur von Ackerunkräutern und deren Einfluß auf die Zusammensetzung von Unkrautgesellschaften. Flora 140: 551-595.

Lawson H.M., Wieseman J.S. 1975. Weed competition. Annu. Reports Scotisch Hortic. Res. Inst. 1974, p. 21.

Lawson H.M., Wieseman J.S. 1978. The effect of weeds on the growth and development of narcissus. J. Appl. Ecol. 15 (1): $257-272$.

Liste der zugelassenen Pflanzenschutzmittel in Deutschland mit Informationen über beendete Zulassungen (Stand: Januar 2013 ) 2013.

Makhteshim Agan. http://www.ma-industries.com, dostęp: 24.02.2013.

Manuja S., Ram R., Singh R., Mukherjee D. 2005. Evaluation of different herbicides for protection of gladiolus (spp.) crop from weeds. Crop Prot. 24 (10): 921-926.

Marcinkowski J. 1975. Wpływ ściółkowania na wzrost, kwitnienie i plon cebul tulipanów odmiany Oxford. [The effect of mulching on growth, flowering and yield of bulbs and tulips]. Prace Inst. Sad., Seria B (1): 139-145.

Margraf K., Albrecht H.J. 1990. Chemische Unkrautbekämpfung bei Zierpflanzen und Ziergehölzen Zierpflanzen; Chemische Unkrautbekämpfung. Dt. Landwirtschaftsverl, Berlin, 128 pp.

Marinangeli P., Castro R.L., Facchinetti C., Reinoso L., Irigoyen J., Curvetto N. 2010. Evaluation of herbicides for chemical weed control in lily bulb production. Weed Technol. 24 (4): 483-488.

Markow M. 1978. Agrofitocenologia nauka o zbiorowiskach roślinnych. PWRiL, Warszawa, 266 ss.

Matyjaszczyk E. 2012. Aktualne możliwości ochrony wybranych upraw małoobszarowych Polsce i w innych państwach Unii Europejskiej. [Current possibilities of selected minor crops protection in Poland and other European Union countries]. Prog. Plant. Prot./Post. Ochr. Roślin 52 (1): 174-177.

Miller T. 2012. Ornamental Bulb, Rhizome, Corm, and Tuber Crops. In: PNW Weed Management Handbook Revised September 2012, Q-15. pnwhandbooks.org/weed/sites/default/files/.../q-nurserygreenhousebulb.pdf, accessed: 24.02.2013.

Miller T., Libbey C. 2000. Weed control in ornamental bulbs. WSU Mount Vernon. http://mtvernon.wsu.edu/weedscience/ publications/Bulb00.pdf, accessed: 24.02.2013.

Miller T., Libbey C. 2012. Testing of several herbicides for use in tulip, daffodil, and bulbous iris. WSSA Annual Meeting. Proceedings. Abstr. 208. Waikoloa, 6-9 February 2012. http://wssaabstracts.com/public/index.php?conf=9, accessed: 24.02.2013.

Mynett M., Jagusz M. 1987. Zwalczanie chwastów w uprawie narcyzów. s. 74-78. W: Materiały z 9. Spotkania Zesp. Herb. Kom. Nauk Ogrod. PAN, Lublin, 16 czerwca 1987. Wyd. ART Olsztyn, 78 ss.

Mynett M., Jagusz M. 1990. Effect of several herbicides on gladiolus plants cultivated from corms and cormels. Acta Hort. 26: 557-560.

Pflanzenschutzmittel-Verzeichnis 2012. Teil 2. Gemüsebau-Obstbau-Zierpflanzenbau. Bundesamt für Verbraucherschutz und Lebensmittelsicherheit Dienststelle Braunschweig, $362 \mathrm{pp}$.

Richardson R.J., Zandstra B.H. 2006. Evaluation of flumioxazin and other herbicides for weed control in gladiolus. Weed Technol. 20 (2): 394-398.

Rola H., Rola J., Zaliwski A. 1999. Monitoring stanu stopnia zachwaszczenia upraw rolniczych w Polsce. [Monitoring of weed infestation of field crop in Poland]. Prog. Plant. Prot./Post. Ochr. Roślin 39 (1): 289-297.

Rolewska Z., Mynett M. 1979. Ocena przydatności kilku herbicydów w uprawie tulipanów. Prace ISiK, Seria B, 4: 121-128.

Rolewska Z., Saniewski M. 1978. Ocena przydatności kilku herbicydów w uprawie mieczyków. Prace ISiK, Seria B, 3: $121-128$.

Rozporządzenie Parlamentu Europejskiego i Rady (WE) NR 1107/2009 z dnia 21 października 2009 r. dotyczące wprowadzania do obrotu środków ochrony roślin i uchylające dyrektywy Rady 79/117/EWG i 91/414/EWG.

Siciński J. 2000. Zbiorowiska chwastów upraw warzywnych w rejonie Łęczycy. Acta Univer. Łódź, Folia Bot. 15: 67-79.

The Pesticides Register Database 2013. https://secure.pesticides.gov.uk, dostęp: 24.02.2013.

Torquand E.D. 1964. Trials of herbicides on narcissus and tulip. p. 235-240. In: Proc. 7th British Weed Control Conf. Brighton, 24-26 November 1964, $437 \mathrm{pp}$.

Waźbińska J., Kawecki Z., Puczel U. 1999. Stan zachwaszczenia ozdobnych roślin jednorocznych. p. 109-114. W: Materiały z 17. Spotkania Zesp. Herb. Kom. Nauk Ogrod. PAN, Skierniewice, 25 maja 1999. Wyd. ART Olsztyn, 145 ss.

Wiśniewska-Grzeszkiewicz H. 1982. Zastosowanie kory surowej i kompostu korowego jako ściółki w uprawie mieczyków. Prace ISiK, Rośliny Ozdobne, Seria B, 7: 91-103.

Zalecenia Ochrony Roślin na lata 2012/13. Cz. IV, Rośliny ozdobne, Rośliny zielarskie. 2012. Inst. Ochr. Roślin - PIB, Poznań,154 ss. 